\title{
THE INFLUENCE OF GEOMETRIC PARAMETERS ON STRENGTH PROPERTIES OF THE AGGREGATES USED TO PRODUCE ASPHALT MIXTURES
}

\author{
Matas BULEVIČIUS ${ }^{\mathrm{a}}$, Kazys PETKEVIČIUS ${ }^{\mathrm{b}}$, Stasys ČIRBA $^{\mathrm{c}}$ \\ ${ }^{a}$ SE “Problematika”, Galves g. 2, 02241 Vilnius, Lithuania \\ ${ }^{b}$ Department of Roads, Vilnius Gediminas Technical University, \\ Saulètekio al. 11, 10223 Vilnius, Lithuania \\ ${ }^{c}$ Department of Mathematical Modelling, Vilnius Gediminas Technical University, \\ Saulètekio al. 11, 10223 Vilnius, Lithuania
}

Received 20 Jun 2013; accepted 03 Oct 2013

\begin{abstract}
Physical and mechanical properties of asphalt mixtures have a significant impact on a condition of fitted pavement, its stability and reliability during the entire period of its operation. These properties not only depend on bituminous binders chosen for an asphalt mixture and properties of mineral filler, but also on geometric and physical properties of the aggregate. An analysis of these indexes showed physical and geometrical indexes of aggregate of different origins (granite, dolomite and gravel). While researching mineral materials used for asphalt mixtures, the values of flakiness and shape index ( $F I$ and $S I)$, impact value $S Z$ and Los Angeles coefficient $L A$ were determined. After calculations, the hypotheses for the average of flakiness and shape indexes of researched rocks (granite, dolomite and gravel) and proximity of dispersions were tested in order to determine the authenticity of geometric quality parameters and similarity of their sampling dispersion. Results of statistical data calculations determined a correlation between geometric parameters of researched aggregate $F I$ and $S I$ and geometrical, strength parameters of the aggregate. The hypotheses, whether research data of these indexes were distributed by normal distribution, were tested by drawing frequency histograms of granite, dolomite and gravel flakiness and shape indexes.
\end{abstract}

Keywords: aggregates; physical and geometrical properties; resistance to fragmentation; flakiness index; shape index; strength; asphalt mixtures.

Reference to this paper should be made as follows: Bulevičius, M.; Petkevičius, K.; Čirba, S. 2013. The influence of geometric parameters on strength properties of the aggregates used to produce asphalt mixtures, Journal of Civil Engineering and Management 19(6): 894-902. http://dx.doi.org/10.3846/13923730.2013.858645

\section{Introduction}

Asphalt concrete mixture is conglomerate material of mineral filler, aggregate and bituminous binder. Quality indexes of asphalt concrete (AC) pavement are significantly influenced not only by bituminous binders, mineral filler, fine and course aggregate, and other components, but also by physical, mechanical, and geometrical properties. In the structure of road pavement (SRC) layers, the aggregate used to produce asphalt mixtures is exposed to static or dynamic, fixed, changing or cyclic loads. AC pavement is disrupted by changes of temperature, rainfall, and other climatic and environmental factors (Petkevičius et al. 2009; Sivilevičius 2011). Authors' works (Timm, Newcomb 2006; Merilla et al. 2006; Loizos 2006; Cheneviere, Ramdas 2006) show that if the non-standard pavement and SRC is designed and fitted properly, the pavement remains sufficiently smooth for a longer period of time (10-20 years and longer) and has less defects. The mechanical strength of mixture can be simulated and experimentally validated by various techniques developed for sandy soils, namely: strength properties developed in Amšiejus et al. (2009), deformation properties developed in Amšiejus et al. (2010).

The analysis of performed works (Kim et al. 2005; Tighe et al. 2007; Lee et al. 2007; Ahammed, Tighe 2008; Li et al. 2008; Lobo-Guerrero, Vallejo 2010) showed that AC pavement, SRC, railway ballast or concrete structures functions in very complex and constantly changing conditions, and is frequently affected by recurring vehicle or other external loads that effects degradation of granular materials.

The degradation of asphalt mixture: membrane of bituminous binder, in its contact with particle of aggregate and the particle (Krabbenhoft et al. 2012). When vehicle loading acts on an asphalt mixture, the internal stress is mainly transferred through the contact points between aggregates (Ma et al. 2012; Alvarez et al. 2010; Markauskas et al. 2010). One of prime reasons of crumble off is the inhomogeneity, shape and size of particles (Sivilevičius, Vislavičius 2008; Mučinis et al. 2009; Mahmoud et al. 2010; Sivilevičius 2011; Vislavičius, Sivilevičius 
2013). Before choosing the aggregate, it is necessary to analyse SRC working conditions (loads, climatic and environmental factors) (Bennert et al. 2011), as well as the requirements for SRC exploitation (Bulevičius et al. 2011). The main geometric parameters of the aggregate used for asphalt mixtures are determined by the indexes of its particle size distribution and relative amount of oblong particles (flakiness $F I$ and shape $S I$ indexes). These quality indexes present mechanical and physical properties of the aggregate in the best way: impact value $S Z$ and Los Angeles coefficient $L A$. All these indexes influence the strength and stability of designed asphalt mixture. Since correlation dependence of different strain aggregate was determined only between their physical and mechanical indexes $S Z$ and $L A$ (Bulevičius et al. 2010), this article seeks to determine how strength properties of particles depend on their geometrical properties. This problem can be solved by analysing dependence of physical and mechanical indexes on geometric indexes of aggregate particles.

It can be hypothesised that resistance of particles to crushing and impact depends on the quantity of flat and oblong particles in the mixture. Therefore, pavement does not collapse longer if the asphalt compound consists of particles that are more resistant to crushing.

The aim of this article is to evaluate means and variance of analysed indexes and obtain the dependence between its geometric and strength parameters using statistical analysis.

\section{Theoretical modelling of the aggregate strength and geometrical dependency indexes}

A principal scheme of how rubble particles break and crumble, while the asphalt layer is influenced by external factors (dynamic and static loads) is presented in Figure 1.
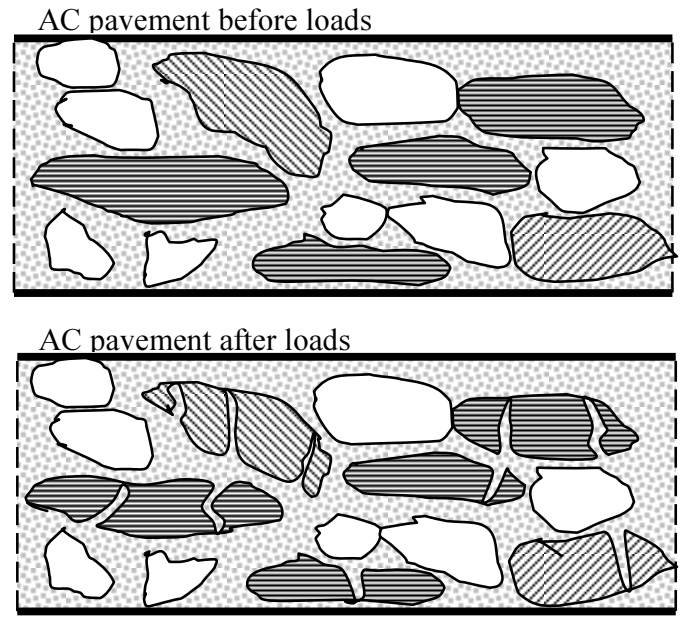

Fig. 1. How aggregate particles break and crumble, while the asphalt layer is influenced by external factors

It is rather easy to notice the dependency between the different strength of aggregate particle and its geometric parameters (theoretical change between $S Z, F I$ and $S I$ is shown in Fig. 2), but in order to figure out how strength indexes $S Z$ and $L A$ depend on the flakiness index $F I$ and shape index $S I$, it is necessary to solve the Eqn (1):

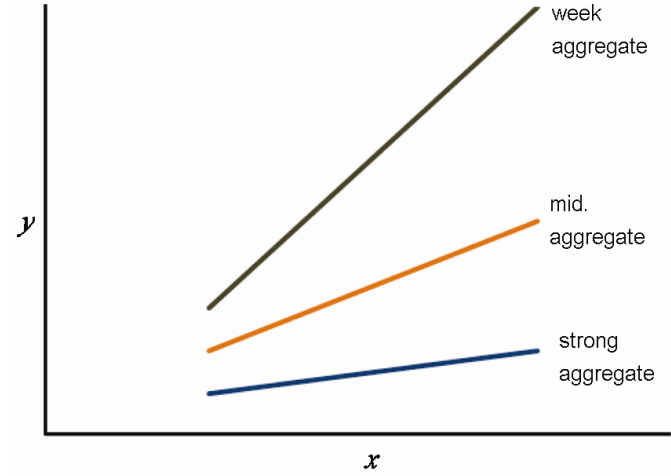

Fig. 2. Theoretical distribution of $S Z, L A$ resistance values according to indexes $F I$ and $S I$

$$
y=a \cdot x+b,
$$

where: $y$ - strength index $(S Z, L A) ; x$ - geometrical index (FI, SI); $a, b$ - const.

The provided graph (Fig. 2) shows a changing tendency in the strength of particles of different mechanical properties. When there are more oblong particles in the mixture, the aggregate tends to be less resistant to crushing.

\section{Experiment}

\subsection{Sampling}

The sample size used for the investigation should be optimal (Cho et al. 2011). Physical, mechanical, and geometrical indexes of various aggregates used for asphalt mixtures kinds produced by seven different manufacturers were analysed for this purpose (Table 1). The Table shows the total sample size and the number of tests of indexes.

Table 1. Number of samples used for the experiment

\begin{tabular}{l|c|c|c|c|c}
\hline \multirow{2}{*}{ Index } & \multirow{2}{*}{$\begin{array}{c}\text { Sample } \\
\text { Rock }\end{array}$} & \multicolumn{4}{|c}{ Number of tests } \\
\cline { 3 - 6 } & & $F I$ & $S I$ & $S Z$ & $L A$ \\
\hline Dolomite & 189 & 102 & 189 & 135 & 21 \\
Granite & 81 & 30 & 71 & 81 & 19 \\
Gravel & 18 & 6 & 13 & 18 & 17 \\
\hline
\end{tabular}

Samples of the aggregates fr. 4/16 were selected in accordance with the method provided in LST EN 9321:2001 standard, namely, taking samples from three different places at different depth of a pile located at a construction site or storage. It was reduced to a necessary size for the test in accordance with the quartering method provided in LST EN 932-2:2002 standard.

\subsection{Test procedure and expression of results}

Flakiness index $F I$ of crushed stone was tested in accordance with the method indicated in standard LST EN 9333:2012. The test consisted of two screening procedures. During the first screening through square sieves, the sample was divided into narrow fractions $d_{i} / D_{i}$ (where: $d_{i}-$ the size of the lower sieve, and $D_{i}$ - the size of the upper sieve). During the second screening, each particle fraction 
$d_{i} / D_{i}$ was sieved through bar sieves, the width of the opening of which was $D / 2$. The total sample flakiness index $F I$ was calculated as the relative amount of particles that passed through the bar sieve from the total mass of dried test portion. Flakiness index $F I$ was calculated using the following equation:

$$
F I=\frac{M_{2}}{M_{1}} \times 100
$$

where: $M_{1}$ - the sum of all the mass fractions $d_{i} / D_{i}$, expressed in grams; $M_{2}$ - the sum of all the mass fractions $d_{i} / D_{i}$ that passed through bar sieves of certain density, expressed in grams.

Shape index $S I$, e.g. the length $L$ and thickness $E$ of particle, was tested with shape measuring calliper (Fig. 3) in accordance with the method indicated in standard LST EN 933-4:2008. Shape index SI of the particles was calculated using the following equation:

$$
S I=\frac{M_{2}}{M_{1}} \times 100
$$

where: $M_{1}$ - the sum of the mass of tested fractions of particles, expressed in grams; $M_{2}$ - the sum of the mass of tested fractions of non-cube-shaped particles, expressed in grams.

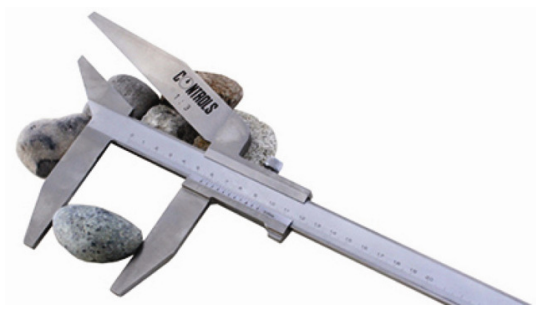

Fig. 3. Shape measuring calliper

The resistance of crushed stone to static and dynamic loading was tested in accordance with the method indicated in standard LST EN 1097-2:2010. LA and SZ indices show the same property of tested material applying different test methods. The Los Angeles method: the $5000 \pm 5 \mathrm{~g}$ sample $(10 / 14 \mathrm{~mm}$ fraction) is placed in a closed drum with ten $\varnothing 45-49 \mathrm{~mm}$ steel balls and rotated 500 revolutions at $31-33 \mathrm{~min}^{-1}$ constant speed. The performance of test using the impact method: a $8 / 12.5 \mathrm{~mm}$ sample fraction was subjected to 10 hammer impacts with a fall height of $370 \mathrm{~mm}$. Upon the performance of tests, the weight loss of material that passed through the control sieve is calculated and expressed as a percentage. The Los Angeles coefficient $L A$ was calculated using the following equation:

$$
L A=\frac{5000-m}{50},
$$

where: $m$ - residue on a $1.6 \mathrm{~mm}$ sieve, g.

Impact value $S Z$ (as a percentage) was calculated using the following equation:

$$
S Z=\left(\frac{M}{5}\right)
$$

where: $M$ - the sum of the mass of particles that passed through 5 analytical sieves, expressed as a percentage.

\subsection{Technical requirements}

Currently, in Lithuania, asphalt mixtures are designed according to TRA ASFALTAS 08 (2009) and the aggregate is selected according to TRA MIN 07 (2007) requirements. These requirements provide categories of quality indexes for asphalt mixtures and select their components. After quality testing of aggregates, data of corresponding results according to TRA MIN 07 (2007) requirements was summarised in Figure 4.

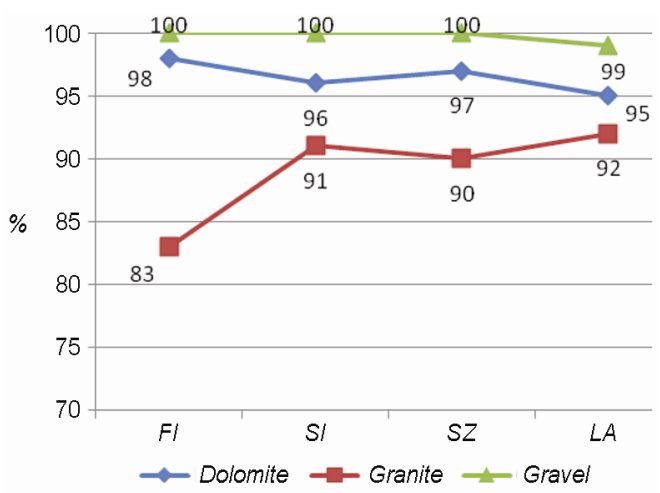

Fig. 4. Summary of results that comply with TRA MIN 07 (2007) requirements

The percentage of index results that comply with the requirements and that are provided in the Figure 4, where results are divided according to the type of rock, range in the close limits, i.e. granite and gravel rock $\pm 1 \%$, and dolomite - up to $6 \%$ it can be argued that the analysed qualitative indexes of rock correlate with each other. In order to analyse how the analysed geometric indexes influence the strength indexes, it is necessary to perform a statistical analysis of the indexes.

\subsection{Mathematical analysis of the aggregate physical and mechanical indexes}

Statistical data necessary for statistical analysis are provided in Tables 2, 3, and 4. Table 2 provides geometric (FI and $S I)$ and strength ( $S Z$ and $L A$ ) quality indexes of granite and dolomite. Statistical data of gravel aggregate quality index are provided in the Table 3, but (due to insufficient data of the flakiness index $F I$ ) statistical calculations were made only for the shape index $S I$ and strength indexes $S Z$ and $L A$. Table 4 provides statistical calculations of all researched strains (granite, dolomite and gravel) of the aggregate geometric indexes ( $F I$ and $S I)$.

The analysis of geometric quality indexes of researched aggregate strength (granite, dolomite and gravel) raised the hypotheses about the correspondence between the flakiness index $F I$ and shape index $S I$ average values and variance. The hypotheses about the correspondence of analysed index average and variance are tested in order to determine whether average and variance of analysed samples are the same. Since the samples of analysed indexes were not the same while testing the hypothesis 
Table 2. Summary of mechanical indexes FI, SI, LA, and $S Z$ of granite and dolomite aggregate

\begin{tabular}{|c|c|c|c|c|c|c|c|c|}
\hline \multirow{4}{*}{ Statistical index $x$} & \multicolumn{8}{|c|}{ Rock } \\
\hline & \multicolumn{4}{|c|}{ granite } & \multicolumn{4}{|c|}{ dolomite } \\
\hline & \multicolumn{8}{|c|}{ indexes of properties and their values } \\
\hline & $F I$ & $S I$ & $L A$ & $S Z$ & $F I$ & $S I$ & $L A$ & $S Z$ \\
\hline Sample size $n$ & 30 & 71 & 19 & 81 & 102 & 189 & 21 & 135 \\
\hline$x_{\min }$ & $1 \%$ & $1 \%$ & 19 & $19.7 \%$ & $1 \%$ & $1 \%$ & 26 & $26.3 \%$ \\
\hline$x_{\max }$ & $21 \%$ & $20 \%$ & 12 & $14.8 \%$ & $18 \%$ & $21 \%$ & 19 & $18.9 \%$ \\
\hline$x_{\max }-x_{\min }$ & $20 \%$ & $19 \%$ & 7 & $4.9 \%$ & $17 \%$ & $20 \%$ & 7 & $7.4 \%$ \\
\hline Mean $\bar{x}$ & $9.20 \%$ & $8.59 \%$ & 15.53 & $17.23 \%$ & $7.14 \%$ & $8.44 \%$ & 21.1 & $22.23 \%$ \\
\hline Standard deviation $s$ & $5.12 \%$ & $3.96 \%$ & 2.11 & $1.13 \%$ & $3.11 \%$ & $3.80 \%$ & 1.56 & $1.36 \%$ \\
\hline Variance $s^{2}$ & $25.23(\%)^{2}$ & $15.66(\%)^{2}$ & 4.46 & $1.27(\%)^{2}$ & $9.69(\%)^{2}$ & $14.41(\%)^{2}$ & 2.42 & $1.84(\%)^{2}$ \\
\hline Skewness $g_{1}$ & 0.42 & 0.63 & -0.83 & 0.14 & 0.62 & 0.56 & 3.40 & 0.72 \\
\hline Kurtosis $g_{2}$ & 2.36 & 2.94 & -0.33 & 0.01 & 3.52 & 3.04 & 1.30 & 0.53 \\
\hline
\end{tabular}

Table 3. Summary of mechanical indexes $S I, L A$, and $S Z$ of gravel aggregate

\begin{tabular}{c|c|c|c}
\hline \multirow{2}{*}{ Statistical index $x$} & \multicolumn{3}{|c}{$\begin{array}{c}\text { Indexes of gravel aggregate properties } \\
\text { and their values }\end{array}$} \\
\cline { 2 - 4 } & $S I$ & $L A$ & $S Z$ \\
\hline Sample size $n$ & 13 & 17 & 18 \\
$x_{\text {min. }}$ & $1 \%$ & 35 & $26.7 \%$ \\
$x_{\text {max. }}$ & $16 \%$ & 21 & $19.1 \%$ \\
$x_{\text {max. }}-x_{\min .}$ & $15 \%$ & 14 & $7.6 \%$ \\
Mean $\bar{x}$ & $7.50 \%$ & 27.05 & $23.47 \%$ \\
Standard deviation $s$ & $5.19 \%$ & 3.99 & $2.19 \%$ \\
Variance $s^{2}$ & $26.92(\%)^{2}$ & 15.94 & $4.79(\%)^{2}$ \\
Skewness $g_{1}$ & 0.14 & -0.18 & -0.66 \\
Kurtosis $g_{2}$ & 1.48 & 0.58 & -0.60 \\
\hline
\end{tabular}

for the proximity of average, the calculations were made by using Fisher's criterion and hypothesis about the proximity of variance by using Bartlett's criterion. The hypotheses were tested by making statistical calculations. While examining the hypotheses about the averages (Eqn (6)) of geometric quality indexes:

$$
T_{\text {stat }}=\frac{\bar{X}-\bar{Y}}{\sqrt{(n-1) \cdot s_{x}^{2}+(m-1) \cdot s_{y}^{2}}} \cdot \sqrt{\frac{m n \cdot(m+n-2)}{n+m}} .
$$

The proximity of variance and the following statistical calculations were made using Eqns (7)-(10):

$$
\begin{gathered}
T=\frac{(N-k) \cdot \ln \cdot s_{P}^{2}-\sum_{i=1}^{k}\left(n_{i}-1\right) \cdot \ln \cdot s_{i}^{2}}{1+\Delta} ; \\
N=n_{1}+n_{2}+\ldots+n_{k} ; \\
s_{P}^{2}=\frac{1}{N-k} \sum_{i=1}^{k}\left(n_{i}-1\right) \cdot s_{i}^{2} ;
\end{gathered}
$$

Table 4. Summary of mechanical indexes FI and SI of all researched strains (granite, dolomite and gravel)

\begin{tabular}{c|c|c}
\hline \multirow{2}{*}{ Statistical index $x$} & \multicolumn{2}{|c}{$\begin{array}{c}\text { Indexes of granite, dolomite, } \\
\text { and gravel aggregate properties and } \\
\text { their values }\end{array}$} \\
\cline { 2 - 3 } & $F I$ & $S I$ \\
\hline Sample size $n$ & 132 & 273 \\
$x_{\text {min. }, \%}, \%$ & 1 & 1 \\
$x_{\text {max. }} \%$ & 21 & 27 \\
$x_{\text {max. }}-x_{\min .}, \%$ & 20 & 26 \\
Mean $\bar{x}, \%$ & 7.61 & 8.44 \\
Standard deviation $s$ & 3.74 & 3.92 \\
Variance $s^{2},(\%)^{2}$ & 13.96 & 15.34 \\
Skewness $g_{1}$ & 0.85 & 0.52 \\
Kurtosis $g_{2}$ & 3.82 & 2.91 \\
\hline
\end{tabular}

$$
\Delta=\frac{1}{3(k-1)} \sum_{i=1}^{k}\left(\frac{1}{n_{i}-1}-\frac{1}{N-k}\right),
$$

where: $\bar{X}, \bar{Y}$ - compared averages of aggregate quality indexes; $n, n_{i}, m$ - samples of indexes (a number of chosen data for verification); $s_{x}^{2}, s_{y}^{2}-$ variance of indexes; $k$ - number of variable samples.

The hypotheses are tested, when significance level of the criterion is $\alpha=0.05$. Used indexes: $g$ - the value of granite aggregate quality index; and $d-$ dolomite and $g r-$ gravel values of aggregate quality index.

\section{Dependency analysis between mechanical, physical, and geometric indexes}

\subsection{Correlation dependencies and regression equation between mechanical, physical and geometric indexes}

According to the requirements of TRA MIN 07 (2007), permissible geometric indexes of the aggregate for the same type of asphalt mixtures are different, therefore, it is necessary to examine and assess correlation dependences 
of researched aggregate flakiness index $F I$ and shape index $S I$ and correlation dependences between geometric and physical quality indexes $L A$ and $S Z$. Correlation dependences of analysed indexes were assessed according to coefficients in the Table 5 .

Table 5. Table for evaluating the nature of correlation (Čekanavičius, Murauskas 2004)

\begin{tabular}{c|l}
\hline $\begin{array}{c}\text { Value of correlation } \\
\text { coefficient }\end{array}$ & \multicolumn{1}{|c}{ Nature of correlation dependence } \\
\hline $0.00-0.19$ & $\begin{array}{l}\text { Very weak dependence or } \\
\text { no dependence at all }\end{array}$ \\
$0.20-0.39$ & Weak dependence \\
$0.40-0.69$ & Average dependence \\
$0.70-0.89$ & Strong dependence \\
$0.90-1.00$ & Very strong dependence \\
\hline
\end{tabular}

Since the aggregate of granite and dolomite is usually used for asphalt mixtures in Lithuania, statistical calculations of quality indexes were made based on these strains of the aggregate.

While determining the correlation dependence of the aggregate flakiness index $F I$ and shape index $S I$, the results were not distinguished by the types of rocks (strains), because only geometric indexes of the aggregate were analysed. The authors determined correlation dependence of physical, mechanical, and geometric indexes of granite between $S I$ and $S Z$, and correlation dependence of physical, mechanical, and geometric indexes of dolomite between: $S I$ and $S Z ; F I$ and $S Z$; SI and $L A ; F I$ and $L A$.
If the sample of analysed indexes $n<10$, results of statistical calculations contain a very large error; therefore, statistical calculations of correlation dependence between the flakiness index $F I$ and impact value $S Z$, shape index $S I$ and the Los Angeles coefficient $L A$, shape index $S I$ and impact value $S Z$, and the flakiness index $F I$ and the Los Angeles coefficient $L A$ were made according to the types of rocks without excluding the quality indexes of analysed aggregate. Statistical calculations are provided in the Table 6.

For the calculation of correlation dependences between the indexes $S I$ and $S Z, 51$ samples of granite, 97 samples of dolomite and 147 samples of granite and dolomite were selected. After statistical calculation of all aggregate strains shape index $S I$ and impact value $S Z$, the authors obtained correlation dependence expressed as correlation coefficient $r=0.19$ for granite, $r=-0.03$ for dolomite and $r=0.15$ for granite and dolomite - very weak dependence or no dependence at all.

After statistical calculation of granite and dolomite aggregate flakiness index $F I$ and impact value $S Z$, flakiness index $F I$ and Los Angeles coefficient $L A$ and shape index $S I$ and Los Angeles coefficient $L A$ the authors determined correlation dependence expressed as correlation coefficient $R$ interval [0.28;0.32], e.g. weak dependence. As, therefore, calculated correlations dependence was expressed as correlation coefficient $r<0.4$ (weak), it makes no sense to evaluate regression equation for these dependences.

Table 6. Summary of correlation dependences between mechanical, physical, and geometric indexes of the analysed aggregate strains (granite dolomite and gravel)

\begin{tabular}{|c|c|c|c|c|c|c|c|c|}
\hline \multirow{2}{*}{ 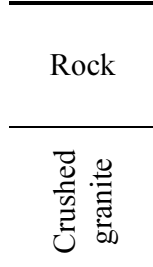 } & \multirow{2}{*}{$\begin{array}{c}\begin{array}{c}\text { Correlation } \\
\text { dependence }\end{array} \\
r\left(x_{S I}, x_{S Z}\right)\end{array}$} & \multirow{2}{*}{$\begin{array}{c}\begin{array}{c}\text { Type of } \\
\text { correlation } \\
\text { dependency }\end{array} \\
\begin{array}{c}\text { very weak } \\
\text { correlation }\end{array}\end{array}$} & \multirow{2}{*}{$\begin{array}{c}\text { Sample } \\
\text { size, } \\
n\end{array}$} & \multicolumn{2}{|c|}{ Mean } & \multicolumn{2}{|c|}{ Variance } & \multirow{2}{*}{\begin{tabular}{|c}
$\begin{array}{c}\text { Correlation } \\
\text { coefficient, } \\
r\end{array}$ \\
\\
\\
0.19
\end{tabular}} \\
\hline & & & & $\bar{x}_{S I}=8.47(\%)$ & $\bar{x}_{S Z}=17.06(\%)$ & $s_{S I}^{2}=14.21(\%)^{2}$ & $s_{S Z}^{2}=1.48(\%)^{2}$ & \\
\hline \multirow{4}{*}{ 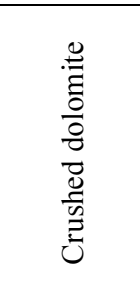 } & $r\left(x_{F I}, x_{S Z}\right)$ & $\begin{array}{l}\text { average } \\
\text { correlation }\end{array}$ & 17 & $\bar{x}_{F I}=8.12(\%)$ & $\bar{x}_{S Z}=21.78(\%)$ & $s_{F I}^{2}=5.87(\%)^{2}$ & $s_{S Z}^{2}=2.19(\%)^{2}$ & 0.57 \\
\hline & $r\left(x_{S I}, x_{S Z}\right)$ & $\begin{array}{l}\text { no correla- } \\
\text { tion at all }\end{array}$ & 97 & $\bar{x}_{S I}=10.13(\%)$ & $\bar{x}_{S Z}=22.12(\%)$ & $s_{S I}^{2}=14.16(\%)^{2}$ & $s_{S Z}^{2}=1.95(\%)^{2}$ & 0.03 \\
\hline & $r\left(x_{F F}, x_{L A}\right)$ & $\begin{array}{l}\text { strong } \\
\text { correlation }\end{array}$ & 18 & $\bar{x}_{F I}=8.12(\%)$ & $\bar{x}_{L A}=21.56$ & $s_{F I}^{2}=8.46(\%)^{2}$ & $s_{L A}^{2}=4.71$ & 0.73 \\
\hline & $r\left(x_{S I}, x_{L A}\right)$ & $\begin{array}{l}\text { average } \\
\text { correlation }\end{array}$ & 20 & $\bar{x}_{S I}=7.94(\%)$ & $\bar{x}_{L A}=21.72$ & $s_{S I}^{2}=11.28(\%)^{2}$ & $s_{L A}^{2}=4.31$ & 0.62 \\
\hline \multirow{4}{*}{ 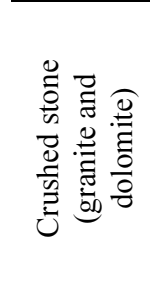 } & $r\left(x_{F I}, x_{S Z}\right)$ & $\begin{array}{c}\text { weak } \\
\text { correlation }\end{array}$ & 22 & $\bar{x}_{F I}=8.12(\%)$ & $\bar{x}_{S Z}=20.46(\%)$ & $s_{F I}^{2}=9.56(\%)^{2}$ & $s_{S Z}^{2}=6.91(\%)^{2}$ & 0.32 \\
\hline & $r\left(x_{S I}, x_{S Z}\right)$ & $\begin{array}{l}\text { very weak } \\
\text { correlation }\end{array}$ & 147 & $\bar{x}_{S I}=9.57(\%)$ & $\bar{x}_{S Z}=20.43(\%)$ & $s_{S I}^{2}=16.71(\%)^{2}$ & $s_{S Z}^{2}=9.71(\%)^{2}$ & 0.15 \\
\hline & $r\left(x_{F I}, x_{L A}\right)$ & $\begin{array}{c}\text { weak } \\
\text { correlation }\end{array}$ & 25 & $\bar{x}_{F I}=7.04(\%)$ & $\bar{x}_{L A}=20.22$ & $s_{F I}^{2}=15.07(\%)^{2}$ & $s_{L A}^{2}=13.88$ & 0.28 \\
\hline & $r\left(x_{S I}, x_{L A}\right)$ & $\begin{array}{c}\text { weak } \\
\text { correlation }\end{array}$ & 27 & $\bar{x}_{S I}=7.47(\%)$ & $\bar{x}_{L A}=20.73$ & $s_{S I}^{2}=14.78(\%)^{2}$ & $s_{L A}^{2}=16.26$ & 0.32 \\
\hline 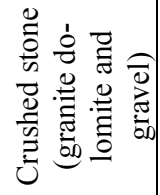 & $r\left(x_{F I}, x_{S I}\right)$ & $\begin{array}{c}\text { strong } \\
\text { correlation }\end{array}$ & 134 & $\bar{x}_{F I}=7.49(\%)$ & $\bar{x}_{S I}=8.02(\%)$ & $s_{F I}^{2}=13.41(\%)^{2}$ & $s_{S I}^{2}=20.58(\%)^{2}$ & 0.74 \\
\hline
\end{tabular}


For the calculation of correlation dependences between the indexes $F I$ and $S I, 134$ samples of different aggregate strains (granite, dolomite and gravel) were selected (Fig. 5).

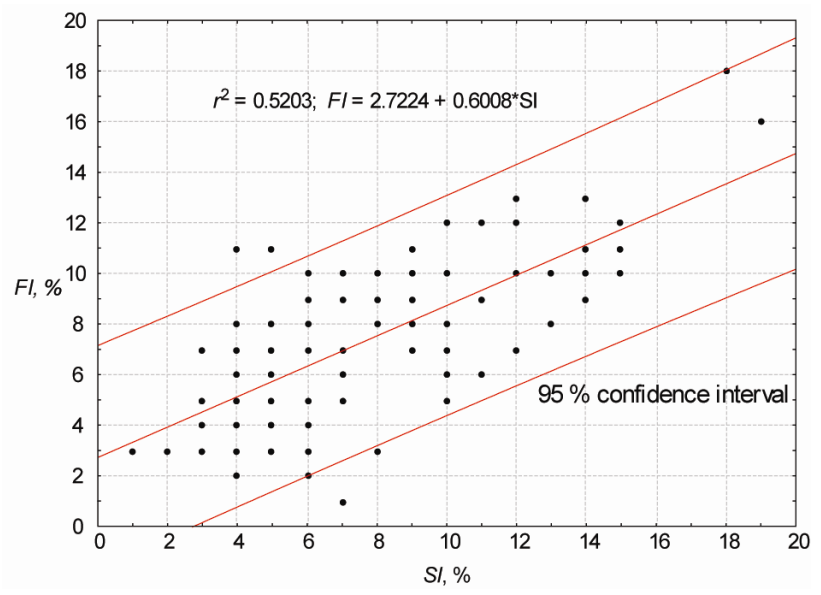

Fig. 5. Dependence between indexes FI and SI of granite, dolomite, and gravel

According to the values of correlation dependence between the indexes $F I$ and SI provided in the Table 6, the authors evaluated the correlation dependence as strong and equation of regression $F I=2.7224+$ $0.6008 \cdot S I$ with coefficient of determination $R^{2}=0.52$. Further in this article for the lack of area calculations without graphics will be shown. For the calculation of correlation dependences between the indexes $F I$ and $S Z$, 17 samples of dolomite were selected. After statistical calculation of dolomite aggregate flakiness index $F I$ and impact value $S Z$, the authors determined correlation dependence between the flakiness index $F I$ and impact value $S Z$ expressed as correlation coefficient $r=0.57$, equation of regression $S Z=18.9547+0.3491 \cdot \mathrm{FI}$, coefficient of determination $R^{2}=0.33$. After statistical calculation of dolomite aggregate flakiness index $F I$ and Los Angeles coefficient $L A(n=18)$, the authors determined correlation coefficient $r=0.64$. Since the values of the indexes $F I$ and $L A(2 ; 22)$ significantly differed from remaining values, the authors of the article rejected the values of these samples. After rejecting the values of the indexes $F I$ and $L A$, the authors obtained the following results: correlation coefficient $r=0.73$ (strong dependence) and equation of regression $L A=18.2916+0.4268$. FI coefficient of determination $R^{2}=0.41$. After statistical calculation of dolomite aggregates shape index $S I$ and
Los Angeles coefficient $L A$, the authors determined correlation dependence between the shape index $S I$ and index of resistance to fragmentation expressed as correlation coefficient $r=0.62$. Since values of the indexes $S I$ and $L A$ were different $(2 ; 22)$, and $(3 ; 23)$ significantly differed from the rest of the values, the authors rejected the values of these samples. After rejecting the values of the indexes $S I$ and $L A$, the authors obtained the results: correlation coefficient $r=0.76$ (strong dependence), equation of regression $L A=19.2469+0.345 \cdot S I$, coefficient of determination $R^{2}=0.39$.

\subsection{Zero hypotheses $H_{0}$ for the proximity of flakiness index $F I$ and shape index $S I$ averages}

After statistical calculations (according to data in the Tables 2, 3 and 4), the authors obtained the following statistical values of geometric quality indexes of granite, dolomite and conjoint strain (granite, dolomite, and gravel) aggregate $F I$ and $S I$ as: averages, number of samples, variance. After placing numbers into the Eqn (6), the authors get $T_{\text {stat }}$. The critical value $T_{\text {crit }}=T_{\frac{0.05}{2} ; n+m-2}$ of

the index was determined from statistical tables. The authors can indicate acceptation of the hypothesis $H_{0}$ for the proximity of flakiness and shape indexes averages after inequality $\left|T_{\text {stat }}\right|<T_{\text {crit }}$ evaluation (Table 7).

After calculation of the statistical values only hypothesis $H_{0}: \bar{X}_{F I g}=\bar{Y}_{S l g}$ for the proximity of granite flakiness and shape indexes averages was not rejected.

Bartlett's criterion checks the hypothesis of dispersion equality. It is applied if the observed variables are distributed normally. In order to check the hypothesis of dispersion proximity between the values of flatness and form indexes, it is purposeful to check whether the analysed geometrical indexes are distributed normally. Hypotheses for the normal distribution of analysed index frequency in the histograms were tested by accepting the level of significance $\alpha=0.05$. Hypotheses for the normal distribution of frequency were tested only for those indexes that had frequency distributed according to the tendency of normal distribution. The hypothesis for the normal distribution of data was tested according to the Eqn (6). Summary of hypotheses for the normal distribution of available data value is provided in the Table 8 .

As all distribution of analysed indexes was stated as normal, hypothesis $H_{\mathrm{o}}$ for the proximity of the flakiness index $F I$ and shape index $S I$ variance can be estimated.

Table 7. Summary of hypotheses for the proximity of indexes FI and SI of the average values of granite dolomite and gravel

\begin{tabular}{|c|c|c|c|c|c|c|c|c|}
\hline \multirow[b]{2}{*}{ Rock } & \multirow[b]{2}{*}{ Hypothesis $H_{0}$} & \multicolumn{2}{|c|}{ Mean, \% } & \multicolumn{2}{|c|}{ Variance, $(\%)^{2}$} & \multirow{2}{*}{$\begin{array}{c}\text { Statistical } \\
\text { value, } \\
T_{\text {stat }}\end{array}$} & \multirow{2}{*}{$\begin{array}{c}\text { Critical } \\
\text { value, } \\
T_{\text {crit }}\end{array}$} & \multirow{2}{*}{$\begin{array}{c}\text { Status of the } \\
\text { hypothesis } \\
H_{0}\end{array}$} \\
\hline & & $\overline{X_{F I}}$ & $\overline{Y_{S I}}$ & $s_{F I}^{2}$ & $s_{S I}^{2}$ & & & \\
\hline crushed granite & $H_{0}: \bar{X}_{F I g}=\bar{Y}_{S I g}$ & 9.20 & 8.59 & 25.23 & 15.66 & 0.09 & 1.99 & accepted \\
\hline crushed dolomite & $H_{0}: \bar{X}_{F I d}=\bar{Y}_{S I d}$ & 7.14 & 8.44 & 9.69 & 14.41 & 3.14 & 1.97 & rejected \\
\hline $\begin{array}{l}\text { crushed granite, } \\
\text { dolomite and gravel }\end{array}$ & $H_{0}: \bar{X}_{F I b}=\bar{Y}_{S I b}$ & 7.61 & 8.44 & 13.96 & 15.34 & 2.49 & 1.97 & rejected \\
\hline
\end{tabular}


Table 8. Summary of hypotheses for the normal distribution of available data value

\begin{tabular}{|c|c|c|c|c|c|c|c|}
\hline Rock & Index & $\begin{array}{l}\text { Sample } \\
\text { size, } \\
n\end{array}$ & $\begin{array}{l}\text { Number of } \\
\text { intervals, } \\
\quad k\end{array}$ & $\begin{array}{l}\text { Length of } \\
\text { intervals, } \\
\quad h\end{array}$ & $\begin{array}{l}\text { Statistical } \\
\text { value, } \\
T_{\text {stat }}\end{array}$ & $\begin{array}{l}\text { Critical } \\
\text { value, } \\
T_{\text {crit }}\end{array}$ & $\begin{array}{l}\text { Status of } \\
\text { the normal } \\
\text { distribution }\end{array}$ \\
\hline $\begin{array}{l}\text { crushed granite } \\
\text { crushed dolomite } \\
\text { crushed granite and dolomite }\end{array}$ & $F I$ value & $\begin{array}{c}30 \\
102 \\
132\end{array}$ & \multirow{2}{*}{5} & $\begin{array}{c}4 \\
3.4 \\
4\end{array}$ & $\begin{array}{l}3.05 \\
0.36 \\
4.83\end{array}$ & $\begin{array}{l}5.99 \\
5.99 \\
5.99\end{array}$ & $\begin{array}{l}\text { accepted } \\
\text { accepted } \\
\text { accepted }\end{array}$ \\
\hline $\begin{array}{l}\text { crushed granite } \\
\text { crushed dolomite } \\
\text { crushed granite, dolomite and gravel }\end{array}$ & $S I$ value & $\begin{array}{c}71 \\
189 \\
273\end{array}$ & & $\begin{array}{c}3.8 \\
4 \\
5.2\end{array}$ & $\begin{array}{l}3.35 \\
5.23 \\
5.67\end{array}$ & $\begin{array}{l}5.99 \\
5.99 \\
5.99\end{array}$ & $\begin{array}{l}\text { accepted } \\
\text { accepted } \\
\text { accepted }\end{array}$ \\
\hline
\end{tabular}

Table 9. Summary of zero hypotheses for proximity between indexes FI and SI of the variance of granite dolomite and gravel

\begin{tabular}{|c|c|c|c|c|c|c|}
\hline Rock & $\begin{array}{c}\text { Hypothesis } \\
H_{0}\end{array}$ & $\begin{array}{c}\text { Sum of sam- } \\
\text { ple size, } \\
N\end{array}$ & $\begin{array}{l}\text { Variance, } \\
s_{p}^{2}\end{array}$ & $\begin{array}{c}\text { Statistical } \\
\text { value, } \\
T\end{array}$ & $\begin{array}{c}\text { Stochastic } \\
\text { number, } \\
\chi_{\alpha}^{2}(k-1)\end{array}$ & $\begin{array}{l}\text { Status of the } \\
\text { hypothesis } H_{0}\end{array}$ \\
\hline crushed granite & $H_{0}: s_{F I g}^{2}=s_{S I g}^{2}$ & 101 & 18.46 & 2.441 & 3.841 & accepted \\
\hline crushed dolomite & $H_{0}: s_{\text {FId }}^{2}=s_{\text {SId }}^{2}$ & 291 & 12.76 & 4.926 & 3.841 & rejected \\
\hline $\begin{array}{l}\text { crushed granite, } \\
\text { dolomite and gravel }\end{array}$ & $H_{0}: s_{F I b}^{2}=s_{S I b}^{2}$ & 405 & 14.89 & 0.387 & 3.841 & accepted \\
\hline
\end{tabular}

\subsection{Zero hypotheses $\boldsymbol{H}_{0}$ for the proximity of flakiness index $F I$ and shape index $S I$ variance}

After statistical calculations (according to data in Tables 2, 3 and 4), the authors obtained the following statistical values of geometric quality indexes of different strains aggregate $F I$ and $S I$ : averages, samples size and variance. Zero hypothesis $H_{0}$ about the proximity of geometrical indexes $F I$ and $S I$ variance can be estimated after statistical values are put into Eqns (6), (7) and (8) (Table 9).

After calculation of the statistical values only hypotheses $H_{0}: s_{F I g}^{2}=s_{S I g}^{2}$ and $H_{0}: s_{F I b}^{2}=s_{S I b}^{2}$ of the proximity of granite, as well as mixture of granite, dolomite, and gravel aggregate $F I$ and $S I$ indexes statistical value $T$, was estimated less than $\chi_{\alpha}^{2}(k-1)$, there is no reason to reject the hypotheses for the proximity of researched aggregate strain flakiness and shape index dispersions.

\section{Conclusions}

The skewness of all analysed geometric quality indexes of the aggregate is $g_{1}>0$; it shows that the right asymmetry case of empiric distribution in the values of samples. The skewness of granite and dolomite aggregate $\left(g_{1}=[0.42 ; 0.62]\right)$ is significantly higher than analogous coefficient of gravel aggregate $\left(g_{1}=0.14\right)$; it means that the values of granite and dolomite aggregate $F I$ and $S I$ are distributed on the left, towards the higher values, average (median), and the values of gravel aggregate are distributed around the middle value. It confirms that the aggregate strains used in Lithuania comply with higher categories of geometric quality indexes.

The test of correlation between quality indexes of different aggregate strains and its strength indexes determined a strong correlation between all values of $F I$ and $S I$, as well as dolomite aggregate indexes $F I$ and $L A$. It shows that both geometric quality indexes of the aggregate are strongly related to each other, the same is with the indexes $F I$ and $L A$. These dependences suggest that determined value of $F I$ may help to predict the value of $L A$. The analysis of correlation dependence between geometrical and strength indexes of different rock samples showed a significant decline of particle strength, when the number of flat and oblong particles was greater.

Similarities of statistical $F I$ and $S I$ averages allowed testing hypothesis about the average proximity of geometric quality indexes. The calculations showed that there is no reason to reject the hypothesis for the average proximity of granite aggregate indexes $F I$ and SI; therefore, it can be argued that while examining geometric indexes ( $F I$ and $S I$ ) of granite aggregate, there is an alternative to choose one of the test methods. However, hypothesis about the average proximity of dolomite aggregate indexes was rejected; it means that while examining the quality of this aggregate, there are no alternatives to choose the test methods.

Only tested hypothesis for the variance proximity of dolomite indexes FI and SI showed that it is rejected; therefore, same hypotheses of granite and mixture of granite, dolomite and gravel were accepted. It can be argued that the values of geometric quality indexes are distributed around the middle value in even intervals.

\section{References}

Ahammed, M. A.; Tighe, S. L. 2008. Statistical modeling in pavement management - do the models make sense, Transportation Research Record 2084: 3-10. http://dx.doi.org/10.3141/2084-01

Alvarez, A.; Mahmoud, E.; Martin, A.; Masad, E.; Estakhri, C. 2010. Stone-on-stone contact of permeable friction course mixtures, Journal of Materials in Civil Engineering 22(11): 1129-1138. http://dx.doi.org/10.1061/(ASCE)MT.1943-5533.0000117 
Amšiejus, J.; Dirgelienè, N.; Norkus, A.; Žilionienė, D. 2009. Evaluation of soil strength parameters via triaxial testing by height versus diameter ratio of sample, The Baltic Journal of Road and Bridge Engineering 4(2): 54-60. http://dx.doi.org/10.3846/1822-427X.2009.4.54-60

Amšiejus, J.; Kačianauskas, R.; Norkus, A.; Tumonis, L. 2010. Investigation of the sand porosity via oedometric testing, The Baltic Journal of Road and Bridge Engineering 5(3): 139-147. http://dx.doi.org/10.3846/bjrbe.2010.20

Bennert, T.; Allen Cooley, L. Jr.; Ericson, C.; Zavery, Z. 2011. Coarse aggregate angularity and its relationship to permanent deformation of gravel-aggregate hot-mix asphalt in New York state, Transportation Research Record 2207(1): 25-33. http://dx.doi.org/10.3141/2207-04

Bulevičius, M.; Petkevičius, K.; Žilionienè, D.; Čirba, S. 2011. Testing of mechanical-physical properties of aggregates, used for producing asphalt mixtures, and statistical analysis of test results, The Baltic Journal of Road and Bridge Engineering 4(2): 115-123.

http://dx.doi.org/10.3846/bjrbe.2011.16

Bulevičius, M.; Petkevičius, K.; Žilioniene, D.; Drozdova, K. 2010. Testing of physical-mechanical properties of coarse aggregate, used for producing asphalt mixtures, and analysis of test results, in Proc. of the $10^{\text {th }}$ International Conference "Modern Building Materials, Structures and Techniques”, 19-21 May, 2010, Vilnius, Lithuania. Vilnius: Technika, 1094-1098.

Cheneviere, P.; Ramdas, V. 2006. Cost benefit analysis aspects related to long-life pavement, International Journal of Pavement Engineering 7(2): 145-152.

http://dx.doi.org/10.1080/10298430600627037

Cho, D.; Najafi, F. T.; Kopac, P. A. 2011. Determining optimum acceptance sample size: second look, Transportation Research Record 2228: 61-69.

http://dx.doi.org/10.3141/2228-08

Čekanavičius, V.; Murauskas, G. 2004. Statistika ir jos taikymai. II knyga [Statistics and its Applications. Book II]. Vilnius: TEV. 272 p.

Dèl automobilių kelių asfalto mišinių techninių reikalavimų aprašo TRA ASFALTAS 08 patvirtinimo [The road asphalt mixtures technical requirements]. Vilnius: Lietuvos automobiliu keliu direkcija prie Susisiekimo ministerijos, 2009, Žin., 2009, Nr. 8-307.

Kim, Y. R.; Allen, D. H.; Little, D. N. 2005. Damage-induced modeling of asphalt mixtures trough computational micromechanics and cohesive zone fracture, Journal of Materials in Civil Engineering 17(5): 477-484.

http://dx.doi.org/10.1061/(ASCE)0899-1561(2005)17: 5(477)

Krabbenhoft, K.; Huang, J.; Vicente da Silva, M.; Lyamin, A. V. 2012. Granular contact dynamics with particle elasticity, Granular Matter 14: 607-619. http://dx.doi.org/10.1007/s10035-012-0360-1

Lee, H. J.; Park, H. M.; Lee, J. H. 2007. Development of a simplified design procedure for determining layer thickness in long-life pavement, Transportation Research Record 2037: 76-85. http://dx.doi.org/10.3141/2037-07

Li, J. H.; Mahoney, J. P.; Muench, S. T.; Pierce, L. M. 2008. Bituminous surface treatment protocol for the Washington state department of transportation, Transportation Research Record 2084: 65-72.

http://dx.doi.org/10.3141/2084-08
Lobo-Guerrero, S.; Vallejo, L. E. 2006. Discrete element method analysis of railtrack ballast degradation during cyclic loading, Granular Matter 8: 195-204. http://dx.doi.org/10.1007/s10035-006-0006-2

Loizos, A. 2006. Assessment and upgrading of in-service heavy duty pavements to long life, International Journal of Pavement Engineering 7(2): 133-144. http://dx.doi.org/10.1080/10298430600627045

LST EN 1097-2:2010. Bandymai užpildu mechaninèms ir fizikinems savybems nustatyti. 2 dalis. Atsparumo trupinimui nustatymo metodai [Tests for mechanical and physical properties of aggregates - Part 2: methods for the determination of resistance to fragmentation]. Vilnius: Lithuanian Standards Board, 2010. 34 p.

LST EN 932-1:2001. Užpildu pagrindiniu savybiu nustatymo metodai. 1 dalis. Eminio émimo metodai [Tests for general properties of aggregates - Part 1: methods for sampling]. Vilnius: Lithuanian Standards Board, 2001. 25 p.

LST EN 932-2:2002. Užpildu pagrindiniu savybiu nustatymo metodai. 2 dalis. Laboratoriniu éminiu dalijimo metodai [Tests for general properties of aggregates - Part 2: methods for reducing laboratory samples]. Vilnius: Lithuanian Standards Board, 2002. 15 p.

LST EN 933-3:2012. Užpildu geometriniu savybiu nustatymo metodai. 3 dalis. Daleliu formos nustatymas. Plokštumo rodiklis [Tests for geometrical properties of aggregates Part 3: determination of particle shape - flakiness index]. Vilnius: Lithuanian Standards Board, 2012. 11 p.

LST EN 933-4:2008. Užpildu geometriniu savybiu nustatymo metodai. 4 dalis. Daleliu formos nustatymas. Formos rodiklis [Tests for geometrical properties of aggregates Part 4: determination of particle shape - shape index]. Vilnius: Lithuanian Standards Board, 2008. $11 \mathrm{p}$.

Ma, T.; Huang, X.; Zhao, Y.; Yuan, H.; Ma, X. 2012. Degradation behavior and mechanism of HMA aggregate, Journal of Testing and Evaluation 40(5): 697-707. http://dx.doi.org/10.1520/JTE20120057

Mahmoud, E.; Gates, L.; Masad, E.; Erdoğan, S.; Garboczi, E. 2010. Comprehensive evaluation of AIMS texture, angularity, and dimension measurements, Journal of Materials in Civil Engineering 22(4): 369-379.

http://dx.doi.org/10.1061/(ASCE)MT.1943-5533.0000033

Markauskas, D.; Kačianauskas, R.; Džiugys, A.; Navakas, R. 2010. Investigation of adequacy of multi-sphere approximation of elliptical particles for DEM simulations, Granular Matter 12: 107-123. http://dx.doi.org/10.1007/s10035-009-0158-y

Merilla, D.; Dommelenb, V. A.; Gasparc, L. 2006. A review of practical experience throughout Europe on deterioration in fully-flexible and semi-rigid long-life pavement, International Journal of Pavement Engineering 7(2): 101-109. http://dx.doi.org/10.1080/10298430600619117

Mučinis, D.; Sivilevičius, H.; Oginskas, R. 2009. Factors determining the inhomogeneity of reclaimed asphalt pavement and estimation of its components content variation parameters, The Baltic Journal of Road and Bridge Engineering 4(2): 69-79. http://dx.doi.org/10.3846/1822-427X.2009.4.69-79

Petkevičius, E.; Laurinavičius, A.; Petkevičius, R.; Babickas, R. 2009. Effect of components content on properties of hot mix asphalt mixture and concrete, The Baltic Journal of Road and Bridge Engineering 4(4): 161-167. http://dx.doi.org/10.3846/1822-427X.2009.4.161-167 
Sivilevičius, H. 2011. Modelling the interaction of transport system elements, Transport 26(1): 20-34. http://dx.doi.org/10.3846/16484142.2011.560366

Sivilevičius, H.; Vislavičius, K. 2008. Stochastic simulation of the influence of variation of mineral material grading and dose weight on homogeneity of hot mix asphalt, Construction and Building Materials 22(9): 2007-2014. http://dx.doi.org/10.1016/j.conbuildmat.2007.07.001

Tighe, S.; Huen, K.; Haas, R. 2007. Environmental and traffic deterioration with mechanistic - empirical pavement design model: Canadian example, Transportation Research Record 1989(2): 336-343.
Timm, D. H.; Newcomb, D. E. 2006. Perpetual pavement design for flexible pavements in the US, International Journal of Pavement Engineering 7(2): 111-119. http://dx.doi.org/10.1080/10298430600619182

TRA MIN 07 Automobiliu keliu mineraliniu medžiagu techniniu reikalavimu aprašas [Description of road minerals' technical requirements]. Vilnius: Lietuvos automobiliu keliu direkcija prie Susisiekimo ministerijos, 2007. 32 p.

Vislavičius, K.; Sivilevičius, H. 2013. Effect of reclaimed asphalt pavement gradation variation on the homogeneity of recycled hot-mix asphalt, Archives of Civil and Mechanical Engineering 13(3): 345-253. http://dx.doi.org/10.1016/j.acme.2013.03.003

Matas BULEVIČIUS. PhD student at the Department of Roads of Environmental Engineering Faculty of Vilnius Gediminas Technical University. He received his Master's degree in 2012 at Vilnius Gediminas Technical University. He is also the author and co-author of 3 publications as well as 4 research and technical reports. He is a chair of the Technical Committee on Road Building Materials and a member of the Technical Committee on Geotechnical Engineering of the Lithuanian Standards Board. His research interests include mechanical-physical properties of aggregates, used for producing asphalt mixtures, and road pavement constructions.

Kazys PETKEVIČIUS. PhD, Eng. Professor at the Department of Roads of Environmental Engineering Faculty of Vilnius Gediminas Technical University. He received his Professor title in 2012 at Vilnius Gediminas Technical University. $\mathrm{He}$ is also the author and co-author of seven books, over 155 other publications as well as over 94 research and technical reports. His research interests include mechanical-physical properties of aggregates, used for producing asphalt mixtures, road pavement constructions, strength, functional design and damages of motor roads.

Stasys ČIRBA. PhD, Eng. Doctor in the Department of Mathematical Modelling of Fundamental Science Faculty at Vilnius Gediminas Technical University. He received his $\mathrm{PhD}$ in 1972 at Vilnius University. He is also the author and co-author of three books, over 20 other publications as well as over 8 research and technical reports. His research interests include statistical and mathematical analysis. 